\title{
Internal Marketing and its relation to Organizational Loyalty among nursing staff
}

\author{
Shereen Faiyez Gabra ${ }^{1}$, Eman Aly Abd-Elhamid ${ }^{2} \&$ Noha Mohamed Rashed ${ }^{3}$. \\ ${ }^{1 .}$ Lecturer of Nursing Administration, Faculty of nursing, Minia University, Egypt. \\ ${ }^{2 .}$ Lecturer of Nursing Administration, Faculty of nursing, Minia University, Egypt. \\ ${ }^{3 .}$ Lecturer of Nursing Administration, faculty of Nursing, Misr University for Science and Technology.
}

\begin{abstract}
:
Background: Internal marketing (IM) is a set of actions done by human resource departments in firms to encourage, educate, and train their staff to deliver better services to customers and increase employee commitment and loyalty to their organization. Aim: Assess Internal Marketing and its relation to Organizational Loyalty among nursing staff. Research design: A descriptive research design. Setting: Minia University Hospital, Egypt Subjects: A convenience sample, for all nurses who agreed to cooperate in the study at the point of data collection was included. The total number was $(n=205)$. Tools: two tools were uses to collect data for the present study; Internal Marketing scale and Organization loyalty questionnaire. Results: There were strong positive correlation and statistically significant between internal marketing and Organizational loyalty for nurses. Conclusion: The present study illustrates four dimensions of internal marketing (Training, Motivation, Team spirit, and Internal communication), which were alternating in their level among nurses. Team spirit is the highest level among other dimensions. The results revealed that two thirds of studied nurses have low level in total internal marketing among nurses at Minia University Hospital. Also, about two thirds of studied nurses have low level in total organizational loyalty level. While there was a positive relation between internal marketing and organizational loyalty for nurses. Recommendations: Internal Marketing core of continuous nursing education, effective communication, motivation, and staff empowerment which it consider a great strategy for the organization to improve organizational loyalty, staff performance and quality of health care services.
\end{abstract}

\section{Keywords: Internal marketing, organizational loyalty \&Nursing staff}

\section{Introduction:}

The $21^{\text {st }}$ century has transported a dramatic change in the structures and strategies of many organizations. These changes have driven the need for organizations to become more marketing-oriented to manage and shop their product/service brand effectively for competitive advantage (Shah \& Murthi, 2021). Internal marketing offers a technique capable of affecting behavioral relationships in the workplace both directly and indirectly (Bailey et al., 2016). Furthermore, through infusing the entire organization with its values through the creation, integration, and communication of those values (Grönroos, 2020). Internal marketing can mediate and/or modify relationships between various employee actions (Nart et al., 2019).

Internal marketing occur when members of an organization try to influence one another. Internal marketing is used by managers to sell an idea up the chain, persuade someone in another department to accomplish something, or persuade a subordinate to take on a difficult task (Shrestha, 2020)

Internal marketing emphasizes the importance of having motivated, contented, and innovative staff for external marketing to succeed. Firms utilize internal marketing to improve their employees' abilities to respond to organizational goals because it provides a unique chance for management to communicate with employees by implementing substantial projects that emphasizes their employee orientation (Sahibzada et al., 2019).

Employees are the organization's first consumers, according to internal marketing (IM), and they can generate, relate to, and even influence the perception of external customers (Bailey et al., 2016). Internal marketing generates an environment that allows managers to concentrate on whatever needs to change internally to improve their external marketplace achievement; internal marketing helps organization's produce excellent customer service by aligning, coordinating, and motivating employees; and internal marketing helps organizations' deliver better customer service by aligning, coordinating, and motivating employees (Abo Soliman et al., 2020). Internal marketing has an impact on three primary areas or components: organizational vision and values, external marketing quality, and interactive marketing quality (Nwoko \& Maduka, 2021). ‘

Internal marketing's goal is to direct employees' attention to internal activities that need to be developed, sustained, and enhanced for the firm to perform better in the external market (Park \& Tran, 2018). 
The internal marketing core can be summarized as focusing on the coordination and motivation of internal employees while engaging, serving, and dealing with external customers to raise consumer expectations (Yildiz, 2014).

Yu et al., (2019) Internal marketing, it is argued, aids an organization's ability to attract and retain great personnel, as well as increases its ability to meet the needs of internal and external clients. Internal marketing strengthens employee loyalty to the organization and instills pride in the organization by providing excellent customer service. Internal marketing also improves employee loyalty and commitment (Suprihanto et al., 2018).

It is tough to find a devoted staff in today's world. Organizational loyalty is defined as promoting the firm to outsiders, remaining loyal to the organization in the face of adversity, and defending and protecting the organization from external dangers (Taahir \& Mohd Remie, 2020).

Because committed and loyal employees reinforce employees' willingness to behave in the best interests of the organizations they work for, organizational loyalty is critical for organizations to maintain a good work environment, recruit and retain a talented, highly motivated, and loyal workforce. Employee loyalty is crucial to the business since employees are a valuable resource, especially since they represent a major investment in terms of recruiting, training, and pay, not to mention benefits, incentives, and rewards (Slimani et al., 2017).

Employee loyalty to the organization refers to their acceptance of the organization's values, attitudes, and beliefs, as well as their willingness to go above and beyond to achieve the organization's goals and objectives. It's multifaceted, involving employees' dedication, attitude, and behavior toward the organization (Dhir et al., 2020).

Employees that are devoted to their organizations' and engaged in their job, according to Sahni (2019), bring competitive advantages to their organizations, such as decreased employee turnover and increased productivity. The importance of workplace loyalty has been recognized all over the world because an organization's performance is greatly dependent on its employees' loyalty (Gouda, 2018).

Managers are having difficulty retaining personnel, which is a matter for concern. A high turnover rate can indicate that an employee isn't loyal to their organization, and it's been said that high employee turnover is a sign of disloyalty (Maloney, 2013). Understanding how to increase employee loyalty can help an organization to reduce staff turnover and improve the security's long-term viability during challenging times. Employees that are loyal are also more likely to work diligently and with devotion.
This will result in a rise in their workplace productivity (Salleh et al., 2017).

Employee loyalty and retention are critical issues currently facing the healthcare industry. To cope with recent challenges within the healthcare industry, managers must engage in the internal marketing of their various services. Internal marketing has been used as an effective management tool to increase employee motivation, satisfaction, and productivity (Adedej \& Ugwumadu, 2018). Internal marketing has a significant impact on employee loyalty. Employee loyalty is also increased when organizations use effective internal marketing methods. Employee organizational loyalty is influenced by internal marketing variables (Chen \& Lin, 2013).

\section{The study Significance:}

Internal marketing is considered one of the most important approaches and is newly driven from industries to health care organizations to deliver valuable customer service which matches customer needs and in turn affects organizational loyalty and organizational commitment for employees.

Internal marketing was becoming more important to health care establishments, especially for hospitals that are facing changing societal and organizational patterns; Nurses come to the health care profession with a misunderstanding of patients' expectations and outcomes of nursing service quality. Ignoring or misunderstanding these expectations and outcomes from nurses is equivalent to sending them to the competition with patients (Ebrahim, 2019).

Internationally various studies have showed that internal marketing is an important factor influencing employee loyalty. Therefore, the primary business concern of health care is to use internal-marketing strategies to effectively enhance and develop the organizational commitment of nurses and reduce turnover to promote organization competitive advantage (Chang \& Chang, 2009).

Chen \& Lin , (2013) had a research to identify effect of internal marketing on organizational loyalty, and showed a significant path coefficient of 0.63 between internal marketing and employee loyalty. Cunha, (2002) stated that employee loyalty increases when provide a good work environment, mutual support and opportunities. These factors and a good work environment are good strategies for internal marketing in organization

In addition, there were rare studies and gap of knowledge in this topic which linked internal marketing and its organizational loyalty, therefore; it was interesting scope for researchers. The present study is unique and new in Egypt. It describes internal 
marketing in health care and its relation to organizational loyalty among nursing staff.

Aim of this Study:

The current study aims to assess internal marketing and its relation to organizational loyalty among nursing staff.

\section{Specific objectives}

- Determine the level of internal marketing among nursing staff at Minia University Hospital.

- Determine the level of organizational loyalty among nursing staff at Minia University Hospital.

- Specify the correlation between internal marketing and organizational loyalty among nursing staff at Minia University Hospital

Research Questions

1. What are the levels of internal marketing among nursing staff at Minia University Hospital?

2. What are the levels of organizational loyalty among nursing staff at Minia University Hospital?

3. Is there a relation between internal marketing and organizational loyalty among nursing staff at Minia University Hospital?

\section{Subject and Methods}

The present study was carried out through: A) Technical design; B) Operational design; C) Administrative design; and D) Statistical design.

\section{Technical design}

The technical design includes the research settings, research design, subjects, and tools for data collection used in the study.

\section{Research Setting:}

The study was conducted at Minia University Hospital, Egypt.

Research Design

To meet the current study's aim, a descriptive correlation design was used.

\section{Subjects}

A convenience sample which represented by all nurses who are working at the Minia university hospital during the time of data collection with total number $($ no= 205) nurses.

Excluded Criteria: nurses who had less than 6 months of experience in current job

Tools of data collection:

Two tools were used to collect the data for this study as follows

Tool I: Internal Marketing scale: it included two parts

- $1^{\text {st }}$ Part: included personal data of nurses as marital status, age, educational qualification, and years of experience.

- $2^{\text {nd }}$ Part: Internal Marketing scale was developed by Adam et al., (2016) to assess internal marketing. Each item was measured by 5 points Likert scale ranged from (1=strongly disagree, $2=$ disagree, $3=$ somewhere, $4=$ agree and $5=$ strongly agree). It included (16 items) with four dimensions as follows: (1) Training (4 items), (2) Motivation (5 items), (3) Team spirit (4 items), and (4) Internal communication (3 items).

Scoring system of this tool was ranged from 16 to 80 and it divided into three levels as follow:

- From 16 to 37 pointed out low internal marketing.

- From 38 to 59 pointed out moderate internal marketing.

- From 60 to 80 pointed out high internal marketing.

Tool II: Organizational loyalty questionnaire.

This questionnaire was developed by Sbiera, (2019); and adopted by researchers to assess organizational loyalty. It consisted of (15 items). Each item was measured by 5 points Likert scale ranged from (1= Never, 2= Seldom, 3= occasionally, 4= frequently and $5=$ Always).

Scoring system was ranged from 15 to 75 and it divided into three levels as follow:

- From 15 to 35 pointed out low organizational loyalty.

- From 36 to 55 pointed out moderate organizational loyalty.

- From 56 to 75 pointed out high organizational loyalty.

Operational design:

The operational design includes Preparatory phase, content validity, reliability, ethical consideration, pilot study and field work

Preparatory phase:

In this phase the researchers have an extensive reviewing of related literature and theoretical knowledge about the study variables to have good insight for study variables by using articles, books, and internet's periodicals and conferences.

Content Validity:

The study face and content validity were examined by a panel of five experts in Nursing Administration field. The recommended modifications were finished to hold out the final version of tools. The tools conceived to be valid from the experts' standpoint.

Reliability:

The tools were verified for dependability by measuring their internal consistency using Cronbach's Alpha coefficient approach. The internal marketing scale for tool one was $(=0.81)$, and the organization loyalty questionnaire for tool two was $(=0.79)$, indicating that the instruments were reliable.

Ethical Considerations:

The Faculty Dean of Nursing at Minia University gave his written approval to conduct the research. Permissions to conduct the research were also secured. The hospital's director and the hospital's 
nursing director. Also, after explaining the study's substance and objective, heads of departments offered their permission and approval. Oral agreement was gained from RN participants after explaining the study's purpose and assuring them that their information would be kept private and utilized solely for research purposes. They also have the option of withdrawing from the study. Following that, they agreed to take part in the research.

\section{Pilot Study:}

A pilot study was carried out to evaluate the tools' clarity and applicability. It was also used to estimate the time needed to fill the tools. It was carried out on $10 \%$ of the total number of subjects (20 nurses). The time required to fill tool one was about 10 to 15 minutes and for tool two about 5-10 minutes. According to pilot study result for two tools they have no changed occurred so, pilot study data were included in the main study sample.

\section{Field work:}

- Official approval was confirmed by the administrator of the hospital and nurse's hospital.
- The researchers clarified the study's aim and significance to each participant to obtain better cooperation during the research's implementation.

- The researchers distributed the study tools to nurses one by one in their units.

- Study tools were expected to take between 20 and 25 minutes to complete.

- The researchers double-checked to ensure that the nurse had accomplished all of the tool's items.

- Data was collected during the morning and afternoon shifts for nearly four months, starting in

October 2020 and ending in January 2021.

\section{Statistical Analysis}

A personal computer was used to gain access and anatomize data. Version 25 of the Statistical Package for Social Studies (SPSS) was used. Frequency, percentage distribution, mean, and standard deviation were all used as descriptive statistics. The Fisherexact test and the t- test were used to compare the results. Pearson's correlation coefficient was used to assess the correlation between variables (r). For the purposes of interpreting the findings of tests of significance, the significance level was set at p0.05.

\section{Results:}

Table (1): Distribution of nursing staff according to their Personal characteristics data (No=205)

\begin{tabular}{|c|c|c|}
\hline \multirow{2}{*}{ Personal characteristics } & \multicolumn{2}{|c|}{ Staff Nurses (205) } \\
\hline & No & $\%$ \\
\hline \multicolumn{3}{|l|}{ 1. Age } \\
\hline$\cdot>30$ & 125 & 60.9 \\
\hline - $30-40$ & 47 & 23 \\
\hline - $<40$ & 33 & 16.1 \\
\hline Mean \pm SD & \multicolumn{2}{|c|}{$31.3 \pm 8.77$} \\
\hline \multicolumn{3}{|l|}{ 2.Sex } \\
\hline Male & 69 & 33.7 \\
\hline - $\quad$ Female & 136 & 66.3 \\
\hline \multicolumn{3}{|l|}{ 3.Marital status } \\
\hline - Single & 60 & 29.3 \\
\hline - $\quad$ Married & 141 & 68.8 \\
\hline Divorce & 1 & 0.5 \\
\hline - $\quad$ Widowed & 3 & 1.4 \\
\hline \multicolumn{3}{|l|}{ 4. Educational qualifications } \\
\hline - Diploma & 97 & 47.3 \\
\hline - Institute & 93 & 45.4 \\
\hline - Baccalaureate & 14 & 6.8 \\
\hline - $\quad$ Other & 1 & 0.5 \\
\hline \multicolumn{3}{|l|}{ 5.Years of experience } \\
\hline$\cdot \quad>5$ & 23 & 11.2 \\
\hline $15-5$ & 108 & 52.7 \\
\hline $15<$ & 74 & 36.1 \\
\hline Mean \pm SD & \multicolumn{2}{|c|}{$11.22 \pm 8.47$} \\
\hline \multicolumn{3}{|l|}{ 6-Residence } \\
\hline : Urban & $\begin{array}{c}66 \\
139\end{array}$ & $\mathbf{3 2 . 2}$ \\
\hline \multicolumn{3}{|l|}{ 7-department } \\
\hline - General & 158 & 77.1 \\
\hline - Critical & 47 & 22.9 \\
\hline
\end{tabular}


Table (2): Distribution of internal marketing and its dimensions among nursing staff (No=205)

\begin{tabular}{|c|c|c|}
\hline Statement & No & $\%$ \\
\hline \multicolumn{3}{|l|}{ Training } \\
\hline Low level & 52 & 25.4 \\
\hline Moderate level & 118 & 57.6 \\
\hline High level & 35 & 17.1 \\
\hline \multicolumn{3}{|l|}{ Motivation } \\
\hline - $\quad$ Low level & 138 & 67.3 \\
\hline Moderate level & 53 & 25.9 \\
\hline • $\quad$ High level & 14 & 6.8 \\
\hline \multicolumn{3}{|l|}{ Team spirit } \\
\hline - Low level & 18 & 8.8 \\
\hline Moderate level & 55 & 26.8 \\
\hline High level & 132 & 64.4 \\
\hline \multicolumn{3}{|l|}{ Internal communication } \\
\hline $\begin{array}{ll}- & \text { Low level } \\
\end{array}$ & 154 & 75.1 \\
\hline Moderate level & 35 & 17.1 \\
\hline High level & 16 & 7.8 \\
\hline \multicolumn{3}{|l|}{ Total internal marketing } \\
\hline - $\quad$ Low level & 138 & 67.3 \\
\hline Moderate level & 53 & 25.9 \\
\hline High level & 14 & 6.8 \\
\hline
\end{tabular}

Table (3): Frequency distribution of organizational loyalty among nursing staff (No=205).

\begin{tabular}{|c|c|c|}
\hline Total Organizational loyalty & No & $\%$ \\
\hline Low level & 135 & 65.9 \\
\hline Moderate level & 48 & 23.4 \\
\hline High level & 22 & 10.7 \\
\hline
\end{tabular}

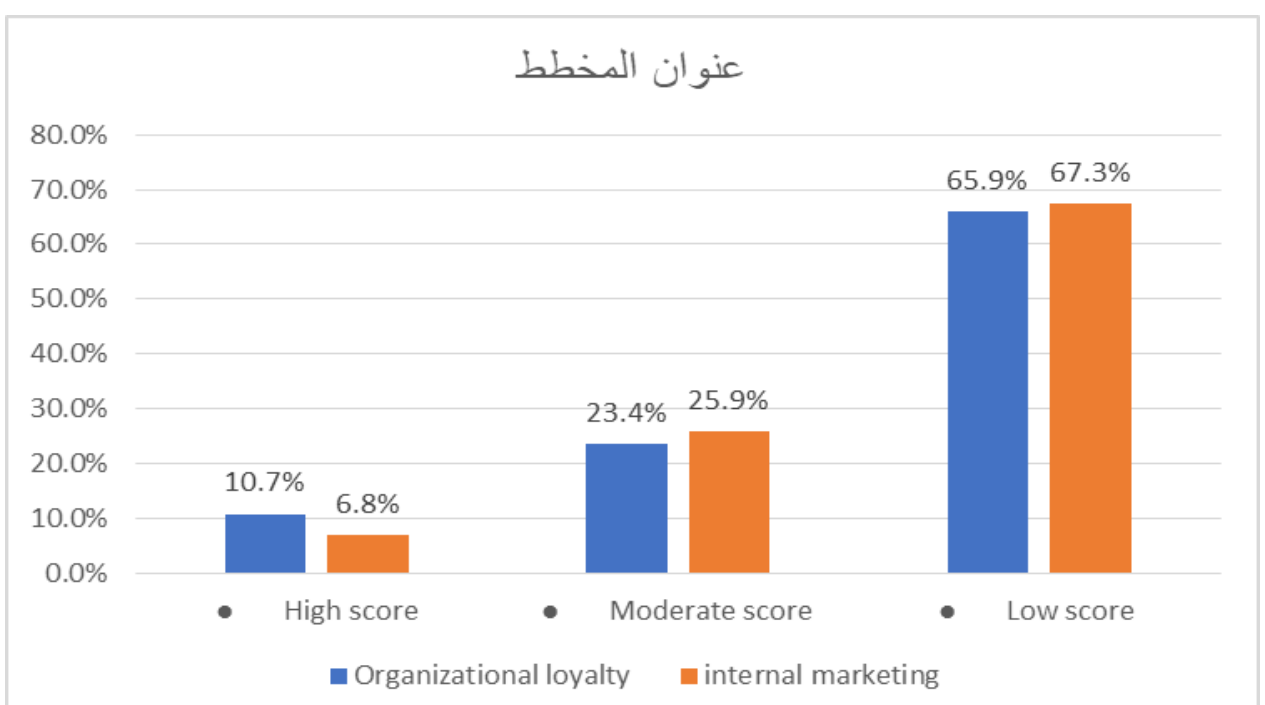

Figure (1): Frequency distribution of total internal marketing and total organizational loyalty among nursing staff $(\mathrm{No}=\mathbf{2 0 5})$.

Table (4): Correlation between internal marketing and organizational loyalty among nursing staff (No=205).

\begin{tabular}{|l|c|c|c|c|}
\hline \multirow{2}{*}{ Variables } & \multicolumn{2}{|c|}{ Internal marketing } & \multicolumn{2}{c|}{ Organizational loyalty } \\
\cline { 2 - 5 } & $\mathrm{r}$ & $\mathrm{P}$ & $\mathrm{r}$ & $\mathrm{p}$ \\
\hline Internal marketing & & & .464 & $.000^{* *}$ \\
\hline Organizational loyalty & .464 & $.000^{* * *}$ & & \\
\hline
\end{tabular}


Table (5): Comparison between mean scores of internal marketing and organizational loyalty among nursing staff regarding to departments $(\mathrm{No}=205)$.

\begin{tabular}{|l|c|}
\hline \multicolumn{1}{|c|}{ Internal marketing } & Mean \pm SD \\
\hline Critical units (47) & $42.71 \pm 9.24$ \\
\hline General units (158) & $40.12 \pm 6.89$ \\
\hline Total number (205) & $41.57 \pm 8.76$ \\
\hline Organizational loyalty & Mean \pm SD \\
\hline Critical (47) & $58.93 \pm 14.8$ \\
\hline General (158) & $56.71 \pm 17.08$ \\
\hline Total number (205) & $57.43 \pm 10.2$ \\
\hline
\end{tabular}

Table (1): Shows that, less than two-thirds (60.9\%) of nurses are in age less than 30 years, about two thirds $(66.3 \%)$ of them are females, more than two third $(68.8 \%)$ of them are married, less than half $(47.3$ $\%)$ of them have nursing diploma more than half of study sample $(52.7 \%)$ have 5-15 years of experience, more than two thirds $(67.8 \%)$ of them are from rural and more than three quarters $(77.1 \%)$ of them are worked in general areas.

Table (2): Summarized that, more than two thirds of studied nurses $(67.3 \%)$ have low total internal marketing level. While more than one quarter of them have moderate total internal marketing level (25.9\%), and only $6.8 \%$ of them have high total internal marketing level

Table (3): Summarized that, about two thirds of studied nurses $(65.9 \%)$ have low organizational loyalty level. While less than one quarter of them have moderate organizational loyalty level $(23.4 \%)$, and only $10.7 \%$ of them have high organizational loyalty level.

Figure (1): Shows that, more than two thirds of studied nurses $(67.3 \%)$ have low total internal marketing level and more than one quarter of them have moderate total internal marketing level (25.9\%). While about two thirds of studied nurses (65.9\%) have low total organizational loyalty level. While less than one quarter of them have moderate total organizational loyalty level (23.4\%).

Table (4): Summarizes that, there are strong positive correlation and statistically significant difference between internal marketing and organizational loyalty for nursing staff $\mathrm{r}=(0.464) \mathrm{P}$-value $=(0.000 * *)$.

Table (5): Indicates that, mean scores of internal marketing for staff nurses in critical areas more than in general areas $\mathbf{( 4 2 . 7 1} \pm \mathbf{\pm 9 . 2 4}, \quad \mathbf{4 0 . 1 2} \pm \mathbf{6 . 8 9}$ ) respectively. And mean scores of organizational loyalty for staff nurses in critical areas more than in general areas $\quad \mathbf{( 5 8 . 9 3} \pm \mathbf{\pm 1 4 . 8}, \quad \mathbf{5 6 . 7 1} \pm \mathbf{1 7 . 0 8})$ respectively.

\section{Discussion}

The internal marketing concept leads the organizations' goals to improve their quality services, increase technological development, achieve clients' needs and expectations, and change consumers purchasing manners, by creating a new culture and developing the performance (Ibrahim \& Yesiltas, 2021). That increases the staff organization's commitment and loyalty. The present study aims to assess internal marketing and its relation to organizational loyalty among nursing staff. The current results illustrate that personal characteristic for the study as the following, about two-thirds of staff nurses were young females, most of them married. The young staff always have energy and dreams and looking for a Career ladder, motivation, and promotion. This staff has needs and expectations from the organization and vice versa the organization too. Also, more than half of them were Diploma nurses and their experience was between 5-15 years. more than two-thirds of them were commuters from a rural area that indicate they were spending a lot of hours on transportation, more cost, more effort. Additionally, more than three-quarters of them prefer to work in the general areas. Also, as normal distribution of hospital beds in adult acute hospitals, the beds at General wards more than critical area's which indicate more nursing staff.

The current study presents four dimensions of internal marketing (Training, Motivation, Team spirit, Internal communication) which shows that more than twothirds of studied nurses have a low total internal marketing level, which could be due to weak leadership and management at the organization. So, the staffing should be one of the main concerns at any health care organization and one of the priorities in organization strategic plan because they are the manpower and first line of health care services. While more than one-quarter of them have a moderate total internal marketing level, and less than ten percent of them have a high total internal marketing level. The health care organization should seek to produce a high level of internal marketing among staff for many reasons that staff will be willing to work for the long 
term, put in extra work when required, engage in many pieces of training, seek for optimum performance, build strong relation in Organization, recommend the organization for family, friends, and others. (Paul, \& Sahadev, 2018). It is expected that internal marketing, could be increase the job satisfaction of nurses, increase the productivity, and quality of health care services.

Lastly, the results showed that the nursing staff has been the highest level of team spirit while the internal communication was the lowest level, and the motivation and training too. It could be due to a good relation they built with each other for this reason the team spirit was high, but the other internal marketing was very low (Motivation, Communication, and training), which need establishing a future vision, and goals at this organization. On researchers point of view those three dimensions very critical items for any organization. It has a positive effect for staff management and their organization loyalty. Especially all previous references recommend for motivating staff nurses, use proper channel for communication and design strategic plan for training of hospital staff.

According to the findings of this study, two-thirds of studied nurses have a low total organizational loyalty level it could be due to a lack of chance for development, training, motivation, dissatisfaction, and reward, this result is agreed with Elizabeth \& Gabriela (2011) who explained that Job satisfaction focused on opportunities for personal skills' development, utilization of strengths, achievement of workplace objectives, Respect for management and pride in the organization were of critical importance to retention; lack of career development plans and opportunities for promotion were key reasons associated with loyalty. This is explained clearly how much low levels of (Motivation, Communication and Training) affect the level of organization loyalty.

The current study revealed that there was a strong positive correlation and statistically significant between internal marketing and organizational loyalty for staff nurses, as an extremely loyal staff is defined as those who feel committed to their organization and plan for staying in an organization and working in the future. This loyalty follow-on the interaction of staff and their health care sitting, engagement in work activities, and their behavior during work. (Alomari et al., 2018).

To remain and accomplish organizational goals and objectives which one of the most challenging concerns for organizations to establish of internal marketing. Health care setting should provide privileges to their staff, to choose an opportunity better for him/her. Also, facilities for learning during work. According to Ibrahim\& Yesiltas, (2021) who had been practical in Iraq reported that there was a positive significant relationship between internal marketing and organization loyalty, it was obliviously improved staff communication with customers, increase job satisfaction, work to maintain the organization goals.

Finally, the existing study reported that internal marketing in critical areas were higher than in general areas, that result could be because the staff nurses in critical wards have been more privileges than staff nurses at a general ward like (salary, incentives, advanced equipment, adequate supplies, quiet environment, training...).

After all the present study shows how much internal marketing affect the total level of organization loyalty of nurse's staff and every and each dimension of internal marketing (Training, Team spirit, Communication, and motivation) get very important to considered during staff management.

\section{Conclusions}

The present study illustrates four dimensions of internal marketing (Training, Motivation, Team spirit, and internal communication), which were alternating in their level among nursing staff. Team spirit is the highest level among other dimensions. The results revealed that two-thirds of studied nurses have a low level in total internal marketing among nursing staff. at Minia University Hospital. Also, about two-thirds of studied nurses have a low level in total organizational loyalty level. While there was a positive relationship between internal marketing and organizational loyalty among nursing staff.

\section{Recommendations}

- Establishment of the internal Marketing as a core of continuing nursing education, effective communication, motivation, and staff empowerment is considered a great strategy for the organization to improve Organizational loyalty, staff performance, and quality of health care services.

- Utilize the internal marketing to treat the nurses with adequate management support which helps them to grow professionally and create a positive environment for Organizational loyalty.

- Develop a strategic plan in healthcare environments to improve internal marketing for organizations that improve quality of care.

- Demonstrate the empowering, and motivating the nurses to use good communication skills, and inspire clear expectations and procedures that increase organizational loyalty and commitment by hospital leaders. 
References

- Abo Soliman, A., El-sayed, N., Ibrahim, S., Inany, E., \& Ibrahim, R. (2020): Assessment of availability of the internal marketing elements at faculty of nursing. Port said scientific journal of nursing, 7(2), 114-132

- Adam, M, Azry. M, Bahisa. H, Tasnem. B, \& Meshika. G. (2016): The Effect of Internal Marketing on Organizational Commitment. International Journal of Academic Research in Economics and Management Sciences, 5(4), 168187

- Adedeji, A., \& Ugwumadu, O. (2018): Comparison of Factors Motivating Different Levels of Management on Employee Loyalty and Retention in Nigerian Deposit Money Banks. Asian Journal of Economics, Business and Accounting, 112.

- Ebrahim, R. (2019): Enhancing Nurses toward Internal Marketing and its Effect on Patients' Outcome at Benha University Hospital. IOSR Journal of Nursing a nd Health Science (IOSRJNHS) e-ISSN: 2320-1959.p- ISSN: 2320-1940 Volume 8, Issue 1 Ser. VII. (Jan. - Feb .2019), PP 28-40. www.iosrjournals.org

- Bailey, A.A., Albassami, F. \& Al-Meshal, S. (2016): "The roles of employee job satisfaction and organizational commitment in the internal marketing-employee bank identification relationship", International Journal of Bank Marketing, Vol. 34 No. 6, pp. 821-840.

- Chang, C., \& Chang, H. (2009): Perceptions of internal marketing and organizational commitment by nurses. Journal of advanced nursing, 65(1), 92100.

- Chen, Y., \& Lin, S. (2013): Modeling internal marketing and employee loyalty: A quantitative approach. Asian Social Science, 9(5), 99.

- Cunha, M. (2002): The best place to be: Managing control and employee loyalty in a knowledgeintensive organization. The Journal of Applied Behavioral Science, 38(4), 481-495.

- Dhir, S., Dutta, T., \& Ghosh, P. (2020): Linking employee loyalty with job satisfaction using PLSSEM modelling. Personnel Review.

- Elizabeth M. Ineson \& Gabriela Berechet (2011) Employee Loyalty in Hotels: Romanian Experiences, Journal of Human Resources in Hospitality \& Tourism, 10:2, 129-149, DOI: 10.1080/15332845.2011.536694

- Gouda, H. (2018): Investigating the Influence of Leadership on Employees' Loyalty in the Private Education Sector in Egypt. International Journal of Humanities and Social Sciences (IJHSS), 7(6), 133 146.
- Grönroos, C. (2020): Co-creation of Value in Service Marketing: An Approach Relevant to Managerial Decision Making. In The Routledge Companion to Strategic Marketing (pp. 261-274). Routledge

- Ibrahim, M., \& Yesiltas, M. (2021): Impact of Internal Marketing on Loyalty, Promotion and Customer Relationship Considering the Mediating Roles of Training, Motivation and Reward. Revista Argentina de Clínica Psicológica, 30(2), 200.

- Khaled A. (2021): The Role of Internal Marketing in Job Satisfaction of Employees in the National Bank of Egypt.

- Maloney, T. (2013): Build Loyalty To Reduce Employee Turnover. The Manager (May 2013).

- Alomari, M, Ali Falah Al-Zoubi \& Fakhrieh Majed Darabseh (2018): The Impact of Factors Affecting Internal Marketing on The Quality of Health Services Provided by Public Hospitals In Amman: An Applied Study. British Journal of Marketing Studies.Vol.6, No.1, pp. 58-78, February 2018 Published by European Centre for Research Training and Development UK. http://www.eajournals.org/

- Nart, S., Sututemiz, N., Nart, S., \& Karatepe, O. (2019): Internal marketing practices, genuine emotions, and their effects on hotel employees' customer-oriented behaviors. Journal of Human Resources in Hospitality \& Tourism, 18(1), 47-70.

- Nwoko, E., Eze, P., \& Maduka, C. (2021): Effect of Internal Marketing on Customer Satisfaction with Telecommunication Companies in Anambra State.

- Park, J., \& Tran, T. (2018): Internal marketing, employee customer-oriented behaviors, and customer behavioral responses. Psychology \& Marketing, 35(6), 412-426.

- Paul, J., \& Sahadev, S. (2018): Service failure and problems: Internal marketing solutions for facing the future. Journal of Retailing and Consumer Services, 40, 304-311

- Sahibzada, U., Jianfeng, C., Latif, F., \& Shafait, Z. (2019): Development and validation of a multidimensional instrument for measuring internal marketing in Chinese higher education. Journal of Enterprise Information Management, Vol. 32 No. 3, 2019

- Sahni, J. (2019): Role of quality of work life in determining employee engagement and organizational commitment in telecom industry. International Journal for Quality Research, 13(2).

- Salleh, L., Samah, B., \& Anwar, M. (2017): Leader Attributes and Effect on Loyalty Among Malaysian Generation Y Public Administrators. Malaysian Institute of Management, 52(1).

- Sbiera. W (2019): the Relationship between Organization Commitment and Job Satisfaction of 
nursing staff at Tishreen University Hospital, Tishreen University Journal for Research and Scientific Studies - Health Sciences Series Vol.(41)No. (5) pp. 313-327

- Shah, D., \& Murthi, B. (2021): Marketing in a data-driven digital world: Implications for the role and scope of marketing. Journal of Business Research, 125, 772-779.

- Shrestha, P. (2020): Managerial Perceptions on Internal Marketing and Employee Commitment in Nepal. Journal of Balkumari College, 9(1), 41-47

- Slimani, I., Douli, S., \& Berbaoui, K. (2017): A Field Study of the Impact of Indirect Compensation on Organizational Loyalty to Workers in NAFTAL (GPL) Bechar Algeria. International Journal of Academic Research in Business and Social Sciences, 7(10), 2222-6990.

- Suprihanto, J., Wrangkani, T., \& Meliala, A. (2018): The relationship between internal marketing and the organizational commitment of doctors and nurses at Mardi Waluyo Hospital, Metro Lampung Indonesia. International Journal of Healthcare Management, 11(2), 79-87.

- Taahir, A., Ng, Y., \& Mohd Remie, M. (2020). The impact of human resource management practices on employee's loyalty in Malaysia. Business and Management, 12(3), 79-93.

- Yildiz, S.M. (2014): "The role of internal marketing on job satisfaction and turnover intention: an empirical investigation of sport and physical activity organizations", Ege Academic Review: Business Administration, International Relations and Political Science, Vol. 14 No. 1, pp. 137-146.

- Yu, Q., Yen, D. A., Barnes, B. R., \& Huang, Y. A. (2019): Enhancing firm performance through internal market orientation and employee organizational commitment. The International Journal of Human Resource Management, 30(6), 964-987 